\title{
Expression of Amplified cDNA Sequences Encoding Human Interleukin 2 in Human Cells
}

\author{
Kazuya OnOmichi, Yuzuru Eto and Hiroshiro ShiBaI \\ Central Research Laboratories, Ajinomoto Co., Inc., 1-1 Suzuki-cho, \\ Kawasaki-ku, Kawasaki 210, Japan
}

Received December 1, 1986

\begin{abstract}
Expression of human interleukin 2 (IL-2) at high levels has been achieved in human cells by cotransfection and subsequent coamplification of the transfected sequences. IL-2 production by these cells reached $2700 \mathrm{U} / \mathrm{ml}$ of culture medium. This productivity was higher than the $100 \mathrm{U} / \mathrm{ml}$ attained by concanavalin A (ConA) stimulated human leukaemic Jurkat, T cells. A plasmid, pSDI, containing human IL-2 cDNA and mouse dihydrofolate reductase (DHFR) cDNA was constructed, and cotransfected with plasmid pSV2neo at a 10:1 molar ratio, into Hela (human epitheloid carcinoma) cells by the DNA-calcium phosphate coprecipitation technique. Transformants producing IL-2 were easily obtained among antibiotic G418 resistant colonies. Cells resistant to increased levels of methotrexate (MTX) secreted a large amount of IL-2 as a result of coamplification of DHFR cDNA and IL-2 cDNA. Expression of IL-2 cDNA was stimulated by removing a G-C stretch which was present between Simian Virus 40 (SV40) early promoter and IL2 cDNA. Plasmid pSDI was rescued from the transformed Hela cells and shown to be present in the intact form among the amplified cellular DNA.
\end{abstract}

Interleukin 2 (IL-2) is a lymphokine produced by lectin- or antigen-activated T cells. ${ }^{1,2)}$ It is required for the proliferation of activated $\mathrm{T}$ cells, the long-term in vitro growth of certain T-cell lines, ${ }^{1,3)}$ augmentation of natural killer cell activity, ${ }^{33)}$ induction of cytotoxic $\mathrm{T}$ cell reactivity, ${ }^{34)}$ and plaque-forming cell responses in culture of nude mouse spleen cells. $^{35)}$ IL-2 is important in vivo as an immunoregulatory substance and may have considerable potential in the treatment of various immunodeficiency syndromes and neoplastic diseases. ${ }^{33,36 \sim 38)}$ The human IL-2 gene has been cloned and characterized at both the $\mathrm{cDNA}^{4,5)}$ and genomic $\mathrm{DNA}^{6 \sim 8)}$ levels. IL-2 is initially synthesized intracellularly as a precursor polypeptide of 153 amino acids, the first 20 of which appear to constitute a signal polypeptide and do not appear in the secreted protein. ${ }^{4)}$ cDNA clones have been used to express recombinant human IL-2 in $E$. coli, ${ }^{5,9)}$ in insect cells, ${ }^{10)}$ and in transfected monkey cells. ${ }^{4)}$

Human IL-2 is glycosylated, ${ }^{28)}$ but further studies are required to characterize it. Bacterially produced human IL-2 is of course nonglycosylated, but it is biologically active. ${ }^{9}$ It is still necessary to do comparative animal studies and possibly clinical trials with IL-2 produced in both animal and bacterial cells, because their pharmacokinetic properties may be different. Some human leukaemic T-cell lines produce IL-2 following stimulation by lectin, but studies on it have been impeded by limited availability of purified material. Recently several eukaryotic host/vector systems have become available for production of large quantities of cloned gene proteins, which are believed to be glycosylated and secreted. Usually rodent cells have been used as the hosts, such as in the efficient production of human interferons by Chinese hamster ovary cells ${ }^{11,12)}$ and mouse cells. ${ }^{13)} \mathrm{A}$ human cell expression system is much more preferable to obtain products closely resembling their native forms, but there have been few reports of human cells being used as hosts for production of proteins via eukaryotic vectors. Yamada et 
$a l$. have tried to express the thymidine kinase gene of herpes simplex virus in human cells using adenovirus vectors. ${ }^{14)}$

Here we have used an amplifiable vector to produce human IL-2 in HeLa cells. We constructed a recombinant plasmid containing human IL-2 cDNA and mouse dihydrofolate reductase (DHFR) cDNA. Since there were no dihydrofolate reductase-negative Hela cells, we could not use DHFR cDNA as a dominant selectable marker. Therefore, this plasmid was introduced into Hela cells by cotransfection with a plasmid carrying a gene for resistance to the antibiotic G418. We were easily able to obtain cell lines containing both plasmids by this cotransfection method.
Cell lines containing multiple copies of the human IL-2 cDNA were selected by exposure to increasing concentrations of the DHFR inhibitor methotrexate (MTX). These cells secreted human IL-2 constitutively.

\section{MATERIALS AND METHODS}

Cell lines. Medium for HeLa cell culture was Dulbecco's modified minimum essential medium (GIBCO Laboratories) containing $2 \%$ fetal bovine serum. Medium for COS-1 cell culture was Dulbecco's modified minimum essential medium containing $10 \%$ fetal bovine serum.

Construction of plasmids. Construction of human IL-2 expression plasmids is shown in Fig. 1. A plasmid pCEIL${ }^{2)}$ (a gift from Dr. H. Matsui) contains a 0.8 kilobase (kb) PstI fragment of human DNA containing IL-2 coding

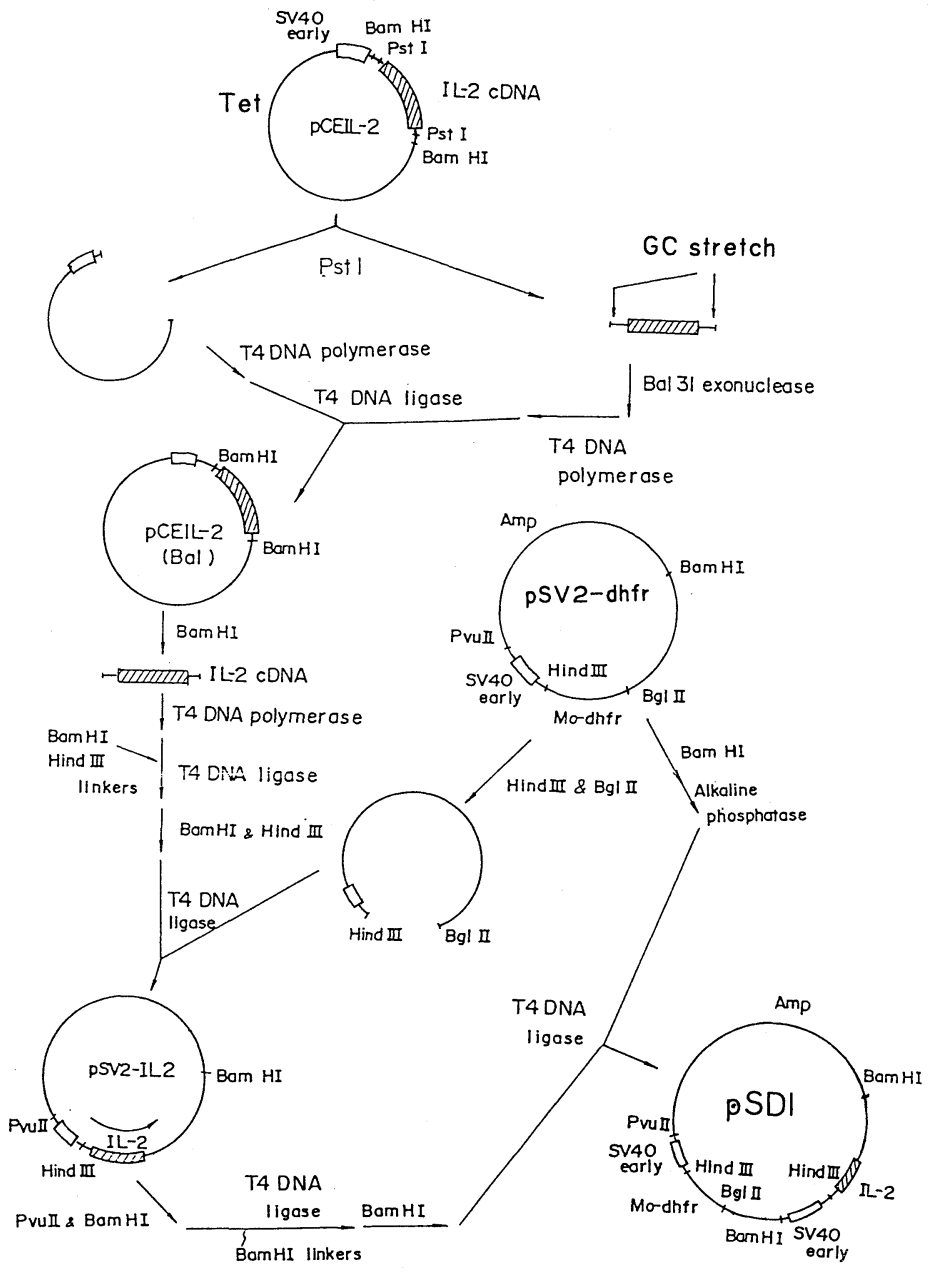

FIG. 1. Construction of Human IL-2 Expression Plasmids. 
sequences. The human IL-2 structural gene can be transcribed from the SV40 early promoter in appropriate host cells. The G-C stretch between the SV40 promoter and cDNA may hamper gene expression, as has already been reported for the expression of human gamma interferon cDNA. ${ }^{16)}$ Therefore, we removed it with nuclease Bal 31 (New England Biolabs) to form the plasmid pCEIL2 (Bal). The IL-2 cDNA fragment was then inserted between HindIII and $B g l$ II cleavage sites in pSV2dhfr, ${ }^{17)}$ a plasmid containing mouse DHFR cDNA immediately downstream of the SV40 early promoter, and upstream of the SV40 early gene splicing and polyadenylation signals. During the insertion the DHFR sequence was lost, and the new IL-2-containing plasmid was called pSV2-IL2, whose structure is shown in Fig. 1. After cleaving this with PvuII and BamHI, a small fragment containing IL-2 cDNA and the SV40 early promoter was purified on an agarose gel, ligated with BamHI linker (Takara Shuzo) and ligated into the single BamHI site of pSV2dhfr to yield pSDI, a plasmid containing both DHFR and IL-2 cDNAs, as well as two SV40 early promoters, as shown in Fig. 1.

Assay for IL-2 activity. IL-2 activity was measured in the IL-2-dependent murine cell line CTLL-2 by measuring [methyl- ${ }^{3} \mathrm{H}$ ] thymidine $\left({ }^{3} \mathrm{H}-\mathrm{TdR}\right)$ incorporation into CTLL-2 cells. ${ }^{18)}$ These cells (4000 per well) were seeded in $100 \mu 1$ of RPMI 1640 : Crick (1:1) medium containing $2 \%$ fetal bovine serum in 96-well flat-bottom microplates, together with $100 \mu \mathrm{l}$ of serially diluted assay samples. After $20 \mathrm{hr}$ at $37^{\circ} \mathrm{C}$, cells were pulse-labelled for $4 \mathrm{hr}$ with $0.5 \mu \mathrm{Ci}$ of ${ }^{3} \mathrm{H}-\mathrm{TdR}$, and collected onto glass fiber strips with an automated cell harvester; the incorporated radioactivity was then measured. One unit per $\mathrm{ml}$ of standard rat IL-2 caused $50 \%$ of the maximal stimulation of ${ }^{3} \mathrm{H}-\mathrm{TdR}$ incorporation.

\section{DNA transfections and selection of transformed cells.}

1) Transient expression assay by monkey COS-1 cells. To confirm IL-2 gene expression by plasmids constructed as shown in Fig. 1, transient expression assays were done using monkey COS- 1 cells. Plasmids containing IL-2 cDNA were transfected into COS-1 cells by a modification of the method of Luthman and Magnusson. ${ }^{19)}$ One day before transfection, COS- 1 cells were plated at a density of $10^{4}$ cells per $\mathrm{cm}^{2}$ in $60 \mathrm{~mm}$ diameter plates with $5 \mathrm{ml}$ of Dulbecco's minimum essential medium (DMEM) containing $10 \%$ fetal bovine serum. The medium was changed $4 \mathrm{hr}$ before transfection. The cells were washed twice with trisbuffered saline (TBS) ${ }^{20)}$ without $\mathrm{MgCl}_{2}$ and $\mathrm{CaCl}_{2}$. Plasmid DNA $(5 \mu \mathrm{g})$ dissolved in $0.8 \%$ TBS, containing $0.5 \mathrm{mg}$ per ml DEAE-dextran (molecular weight $5 \times 10^{5}$; Pharmacia Fine Chemicals), was added to the cell monolayers and incubated for $1 \mathrm{hr}$ at $37^{\circ} \mathrm{C}$. After removing the DNA cocktail, the cells were overlaid with $3 \mathrm{ml}$ of medium containing $150 \mu \mathrm{M}$ chloroquine (Sigma), and were incubated for $3 \mathrm{hr}$ at $37^{\circ} \mathrm{C}$. The cells were then washed twice with TBS without $\mathrm{MgCl}_{2}$ and $\mathrm{CaCl}_{2}$, fed with $4 \mathrm{ml}$ of medium, and incubated overnight at $37^{\circ} \mathrm{C}$. After $16 \mathrm{hr}$, cells were provided with $3 \mathrm{ml}$ of fresh medium and incubated for a further 2 days at $37^{\circ} \mathrm{C}$. Medium was then collected from each dish and assayed for IL-2.

2) Transfection of HeLa cells and selection of transformed cells. Before transfection, the plasmids pSDI and pSV2neo were linearized with $P v u I I$ for efficient transformation. pSDI plasmid DNA (38 $\mu \mathrm{g}$ for $1 \times 10^{6}$ cells) was cotransfected into HeLa cells with pSV2neo $(4 \mu \mathrm{g})^{21)}$ by the calcium phosphate precipitation method. ${ }^{22)}$ After $4 \mathrm{hr}$, the cells were treated with a $20 \%$ glycerol shock for three minutes. After $48 \mathrm{hr}$, the cells were transferred to selection medium containing $800 \mu \mathrm{g} / \mathrm{ml}$ of the antibiotic G418 (GIBCO), which was replenished twice a week. After 3 weeks, independent colonies were picked and transferred to a 24-well plate. G418-resistant colonies were further selected by exposure to increasing concentrations of MTX as described by Ringold et $a .^{23)}$

Genomic DNA blot analysis. Total cellular DNA was prepared from parental and cDNA recipient cell lines by the method of Maniatis et al. ${ }^{24)}$ DNA $(10 \mu \mathrm{g})$ was digested to completion and electrophoresed on $0.8 \%$ agarose gels for Southern blot transfer. ${ }^{25)}$ After staining with ethidium bromide to ensure appropriate DNA sizing, the gel was left on a short $(254 \mathrm{~nm})$ wavelength $\mathrm{UV}$ transilluminator for $20 \mathrm{~min}$. The gel was washed with $0.5 \mathrm{M} \mathrm{NaOH}-1.5 \mathrm{M}$ $\mathrm{NaCl}$ for $45 \mathrm{~min}$ and then with $0.5 \mathrm{M}$ Tris-chloride $(\mathrm{pH}$ 7.5)-3 $\mathrm{M} \mathrm{NaCl}$ for $1 \mathrm{hr}$. The DNA was transferred to nylon membranes (Amersham) by blotting overnight in $10 \times \mathrm{SSC}$ $(0.15 \mathrm{M} \mathrm{NaCl}$ plus $0.015 \mathrm{M}$ sodium citrate). Blotted nylon membranes were wrapped in a plastic film (Saran Wrap; Asahi-Kasei) and placed, DNA side down, on a standard UV transilluminator for $5 \mathrm{~min}$. Filters were then washed for at least $3 \mathrm{hr}$ in hybridization solution $(6 \times \mathrm{SSC}$, $5 \times$ Denhardt's solution, ${ }^{24)} 0.5 \%$ sodium dodecyl sulfate (SDS), and $250 \mu \mathrm{g}$ of denatured salmon sperm DNA per $\mathrm{ml})$ at $65^{\circ} \mathrm{C}$. Fresh hybridization solution and ${ }^{32} \mathrm{P}$-labeled DNA were added and incubated overnight at $65^{\circ} \mathrm{C}$. Filters were washed twice in $2 \times \mathrm{SSC}$, for $15 \mathrm{~min}$ each, once in $2 \times$ SSC containing $0.1 \%$ SDS for $30 \mathrm{~min}$, and once in $0.1 \times \mathrm{SSC}$ for $10 \mathrm{~min}$ at $65^{\circ} \mathrm{C}$ before autoradiography. Filters to be reprobed with different DNA sequences were incubated at $45^{\circ} \mathrm{C}$ for $30 \mathrm{~min}$ in $0.4 \mathrm{M} \mathrm{NaOH}$, then at $45^{\circ} \mathrm{C}$ for $30 \mathrm{~min}$ in $0.1 \times \mathrm{SSC}, 0.1 \% \mathrm{SDS}, 0.2 \mathrm{M}$ Tris $-\mathrm{HCl}(\mathrm{pH}$ 7.5 ), and were autoradiographed overnight to ensure removal of all radioactivity before rehybridization.

DNA sequence analysis. The G-C stretch in IL-2 cDNA was removed by nuclease $\mathrm{Bal} 31$. To confirm its removal, the nucleotide sequence of each terminal region of the cDNA was established by the M13 dideoxy chaintermination $\operatorname{method}^{26)}$ using the M13 sequencing kit (Takara Shuzo)

Rescue of amplified DNA by bacterial transformation. DNA $(10 \mu \mathrm{g})$ from HeLa-pSDI-R200 was digested to 
completion with either of the restriction enzymes $P v u \mathrm{II}$ or $B a m$ HI. After digestion, the reaction mixture was heated for $20 \mathrm{~min}$ at $68^{\circ} \mathrm{C}$, extracted with phenol once and $\mathrm{CHCl}_{3}$ /isoamylacohol $(24: 1)$ once, and precipitated with ethanol. The DNA was dissolved in T4 DNA ligase buffer (66 mM Tris- $\mathrm{HCl}$, pH 7.6, $6.6 \mathrm{~mm} \mathrm{MgCl}_{2}, 10 \mathrm{~mm}$ dithiothreitol (DTT), 1.0 mM ATP). T4 DNA ligase was added and incubated at $4{ }^{\circ} \mathrm{C}$ overnight. The reaction products were used to transform competent $E$. coli $\mathrm{DH} 1$.

\section{RESULTS}

\section{Construction of the IL-2 expression vector}

The G-C stretch in IL-2 cDNA plasmids was removed by nuclease Bal 31 from two clones, pCEIL-2(Bal)C1.7 and C1.14. To certificate its removal, the nucleotide sequence of each terminal region of the IL-2 cDNA was established as shown in Fig. 2. Plasmid pCEIL-2 contained more than 25 bp of G-C in both terminal regions. The IL-2 cDNA of pCEIL-2(Bal)C1.7 began 2 bp upstream of the first ATG triplicate, the initiation codon, and ended in a 6 bp G-C stretch. That of pCEIL2(Bal)C1.14 began $47 \mathrm{bp}$ upstream of the first ATG and ended in a 2 bp G-C stretch. Thus the G-C stretch which had been between the SV40 promoter and the IL-2 cDNA was completely removed from both plasmids. They were transfected into monkey COS-1 cells by

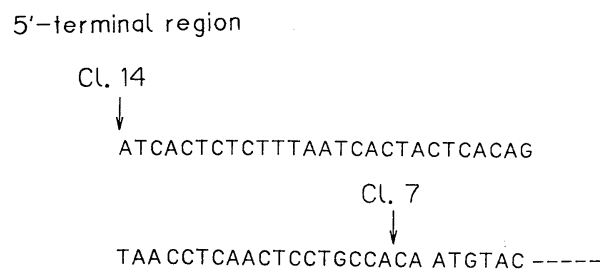

3 -terminal region

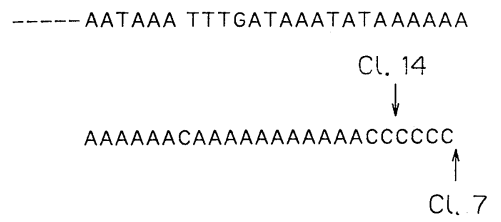

FIG. 2. 5' and $3^{\prime}$-Terminal Regions of the IL-2 cDNA of pCEIL-2(Bal). the DEAE-dextran method. After $72 \mathrm{hr}$, supernatants from the transfected cells were assayed for IL-2 activity (Table I). Plasmid pCE-1, which was constructed by removing the IL-2 cDNA sequences from plasmid pCEIL-2, was used as a negative control. The IL-2 activity was increased by removal of the G-C stretch, so, pCEIL-2(Bal)C1.7 and $\mathrm{C} 1.14$ were used for further experiments.

The IL-2 cDNA fragments of pCEIL2(Bal)C1.7 and $\mathrm{C} 1.14$ were inserted singly between the HindIII and $B g l$ II sites of pSV2dhfr to yield pSV2-IL2 C1.7 and C1.14, respectively. They contained human IL-2 cDNA immediately downstream of the SV40 early promoter and upstream of the SV40 early gene splicing and polyadenylation signals. Since pSV2-IL2 C1.7 was more active than pSV2-IL2 C1.14 in producing IL-2 by the transient expression assay in COS-1 cells (Table I), a small fragment of pSV2-IL2 C1.7 cleaved with PvuII and BamHI was used to construct the plasmid pSDI (Fig. 1), the hybrid

Table I. Increase in IL-2 Activity in the Culture Media of COS-1 Cells Transfected by Plasmids FROM WHICH THE G-C STRETCH HAD BEEN REMOVED

\begin{tabular}{lc}
\hline Transfected DNA & IL-2 activity $(\mathrm{U} / \mathrm{ml})$ \\
\hline pCEIL-2 & 5.4 \\
pCEIL-2(Bal)Cl.7 & 27.0 \\
pCEIL-2(Bal)Cl.14 & 19.7 \\
pSV2IL-2(Bal)Cl.7 & 22.9 \\
pSV2IL-2(Bal)Cl.14 & 18.6 \\
pSDI & 24.8 \\
\hline
\end{tabular}

Table II. Production of Human IL-2 from HeLa Cells

In all cases, cells were seeded at a density of $1.0 \times 10^{5}$ cells per ml. After 4 days, cell supernatants were assayed for IL-2 activity.

\begin{tabular}{lc}
\multicolumn{1}{c}{ Cell line } & IL-2 produced $(\mathrm{U} / \mathrm{ml})$ \\
\hline HeLa & $<1$ \\
HeLa-pSDI-R20 & 110 \\
HeLa-pSDI-R100 & 700 \\
HeLa-pSDI-R200 & 1,500 \\
HeLa-pSDI-R400 & 2,700 \\
\hline
\end{tabular}


containing both IL-2 and DHFR cDNAs, which expressed IL-2 in COS-1 cells (Table I).

\section{Production of IL-2 activity in HeLa cells}

Plasmid pSDI was introduced into HeLa cells by cotransfection with plasmid pSV2neo, which conferred resistance to the neomycin analog G418. G418-resistant colonies (19 clones) were picked after 3 weeks in selection medium containing G418 $(800 \mu \mathrm{g} / \mathrm{ml})$; colonies were obtained only if pSDI was transfected with pSV2neo. HeLa-pSDI colonies were further selected by exposure to increasing concentrations of MTX, and were then examined for their IL-2 productivity. Since MTX might be harmful to CTLL-2 cells in the IL-2 assay, HeLa cell culture medium to be tested in the IL-2 assay was exchanged for fresh medium containing no MTX, and supernatants were collected at appropriate intervals. The supernatants of 12 actively growing clones were assayed for IL-2 activity, and constitutive secretion was detected in 11 of them. Table II shows that HeLa-pSDI derivatives resistant to 20, 100, 200, and 400 nM MTX (designated HeLa-pSDI-R20, HeLa-pSDI-R100, HeLapSDI-R200, and HeLa-pSDI-R400, respectively) constitutively produced increasing levels of IL-2. HeLa-pSDI-R400 cells continued to produce IL-2 stably for at least 1 month.

\section{Increased IL-2 expression as a result of gene amplification}

Schimke et al. ${ }^{26}$ ) have shown that the DHFR gene could be amplified by exposure of mouse cells to increasing MTX concentrations. Recombinant plasmids containing DHFR cDNA as well as DHFR genes within their normal host can be amplified. ${ }^{23)}$ Southern blot analysis was done on DNA from HeLa and HeLa-pSDI-R200 cells to find whether gene amplification had occurred in

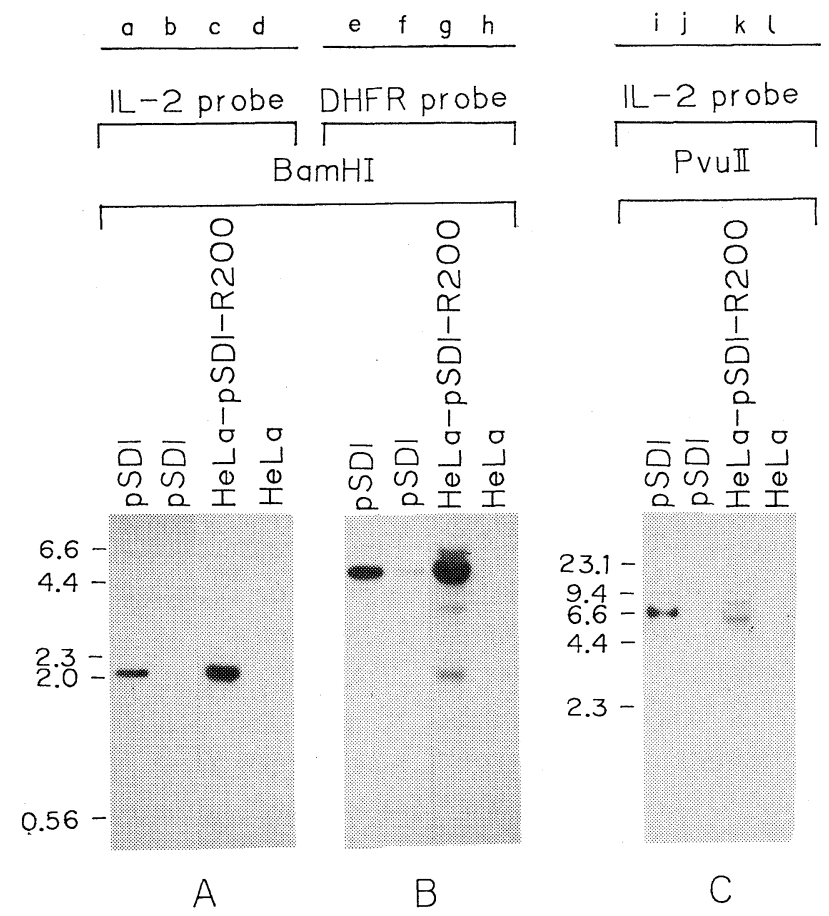

FIG. 3. Southern Blot Analysis of DNA from HeLa-pSDI-R200 Cells and HeLa Cells.

DNA was digested to completion with BamHI (lanes a through h) and PvuII (lanes i through 1). Samples $(10 \mu \mathrm{g})$ of genomic DNAs were put on a $0.8 \%$ agarose gel. Samples of $2.3,0.23,2.3,0.23,2.3$, and $0.23 \mathrm{ng}$ of plasmid pSDI were put in lanes $\mathrm{a}, \mathrm{b}, \mathrm{e}, \mathrm{f}, \mathrm{i}$, and $\mathrm{j}$, respectively. Panels A and $\mathrm{C}$ were probed with ${ }^{32} \mathrm{P}$-labeled human IL-2 cDNA, and panel B was probed with ${ }^{32} \mathrm{P}$-labeled mouse DHFR cDNA. 
these cells. BamHI and PvuII-digested genomic DNA was electrophoresed and analyzed by Southern hybridization. The probe used was either a radioactively labeled human IL-2 cDNA fragment or a mouse DHFR cDNA fragment (both about $0.8 \mathrm{~kb}$ ). Figures $3 \mathrm{~A}$ and $3 \mathrm{C}$ show that human IL-2 cDNA was abundunt in HeLa-pSDI-R200 cells. On the other hand, human IL-2 DNA could not be detected in ordinary HeLa cells by autoradiography for 5 days. HeLa-pSDI-R200 was found to contain about 200 copies of human IL-2 cDNA by inspection of the autoradiograms (pSDI DNA was put onto the gels at concentrations corresponding to 10 and 100 copies per cell) and by another DNA dot-blot analysis (not shown). The nylon filters used in Fig. $3 \mathrm{~A}$ were stripped of hydridizing IL-2 cDNA fragments and reprobed with a labeled mouse DHFR cDNA fragment. Figure 3B shows that the mouse DHFR cDNA was also amplified in HeLa-pSDI-R200. Several minor sequences were detected in HeLa-pSDI-R200 in addition to bands of the same size as pSDI DNA (Figs. 3B and 3C). Human IL-2 mRNA in HeLa-pSDI-R200 was detected by dot-blot analysis (not shown) with a ${ }^{32} \mathrm{P}$-labeled probe prepared by nick translation of the $0.8 \mathrm{~kb}$ IL-2 cDNA fragment.

\section{Rescue of the transforming $D N A$}

Since pSDI plasmid DNA sequences appeared intact by blot analysis, attempts were made to rescue these sequences by bacterial transformation. Genomic DNA was digested with PvuII or BamHI, circularized with T4 DNA ligase, and used to transform $E$. coli DH1 to ampicillin resistance. Using HeLapSDI-R200 cell DNA, 24 resistant colonies were recovered (16 plasmids rescued from $P v u I I-c l e a v e d$ DNA and 8 plasmids rescued from BamHI-cleaved DNA.) Five plasmids rescued from each restriction enzyme-cleaved cellular DNA were randomly selected and screened. All five plasmids rescued from BamHI-cleaved DNA were identical to the large fragment of BamHI-digested pSDI plasmid DNA. Of five plasmids rescued from
PvuII-cleaved DNA, three were identical to pSDI plasmid DNA, but the other two were larger than the pSDI DNA plasmid. Due to differences in restriction maps these plasmids were thought to contain DNA not derived from the original plasmid pSDI (data not shown).

\section{DISCUSSION}

The purpose of this investigation was to apply gene amplification to the development of a human cell line producing high levels of IL-2. Plasmid DNA containing the human IL-2 cDNA and mouse DHFR cDNA was transfected into human (HeLa) cells. The cells resistant to increased levels of MTX, in other words, those expressing the DHFR gene at a high level, secreted large amounts of IL-2 as a result of coamplification of the DHFR and IL-2 genes. Thus, the HeLa-pSDI cell, supplemented with plasmids containing DHFR and IL-2 genes, could be induced to become resistant to $400 \mathrm{~nm}$ MTX, and produce at the same time up to $2700 \mathrm{U} / \mathrm{ml} \mathrm{IL}-2$. The rate of production of human IL-2 from HeLa-pSDI may increase further following selection of resistant cell lines in higher concentrations of MTX. Production of human IL-2 by Chinese hamster ovary cells has also been attempted using these gene amplification vectors. IL-2 titers of $95000 \mathrm{U} / \mathrm{ml}$ (about $2 \mathrm{mg} / \mathrm{l}$ ) medium were achieved by a genetically derived cell line resistant to $40000 \mathrm{~nm}$ MTX. The productivity by this cell line increased more than 20 fold above that of a cell line resistant to $400 \mathrm{~nm}$ MTX (unpublished data).

Application of the transformed HeLa cells to practical production of human IL-2 has advantages over the method using ConAstimulated human leukaemic Jurkat $T$ cells, for the following three reasons. First, IL-2 productivity by the transformed HeLa cells was $2700 \mathrm{U} / \mathrm{ml}$, compared to $100 \mathrm{U} / \mathrm{ml}$ by ConA-stimulated Jurkat cells. Secondly, the transformed HeLa cells produced IL-2 constitutively, but Jurkat cells needed ConA induction. This property would be favorable for 
long-term production using hollow fiber culture systems. Thirdly, scale-up of the IL-2 production system would be easier and more practical due to the absence of an induction process, thus avoiding large scale replenishment with freshly prepared medium. Medium costs would be double in ConA-stimulated Jurkat cells, since fresh serum-containing medium is required twice at the growth- and induction-phases.

Human cells deficient in the DHFR gene would be preferable as a host cell, although DHFR-positive HeLa cells were employed in our experiments. Cells containing only transfected DHFR genes could be easily selected on the basis of their ability to grow in the absence of nucleosides, thus avoiding antibiotic resistance cotransfection procedures. Furthermore, subsequent amplification of the DHFR gene in such cells would always result in coamplification of the adjacent IL-2 gene. In the case of naturally DHFR-positive cells, on the other hand, the native DHFR genes can also be amplified in the presence of MTX, resulting in inefficient coamplification of the IL-2 gene. Therefore, isolation of human cells deficient in the DHFR gene might be required as an initial step in the genetic breeding of IL-2 overproducing cells. Such an attempt would be extremely difficult in diploid eukaryotic cells.

Chinese hamster ovary cells which are deficient in $\mathrm{DHFR}^{29)}$ have been used as hosts to produce high levels of gamma interferon, ${ }^{11,30}$ beta interferon ${ }^{12)}$ and tissue-type plasminogen activator $^{31)}$ by application of gene amplification vectors. As it is not known whether glycosylation in hamster and human cells leads to identical structures, it may be more appropriate to generate and use a human DHFRnegative cell line for the production of human glycoproteins. However, since it is tedious to generate a human DHFR-negative cell line, a cotransfection method was used in our experiments to transfect plasmid DNA containing IL-2 cDNA and DHFR cDNA into DHFRpositive HeLa cells. As a result, transformed HeLa cells producing high levels of IL-2 were obtained following gene amplification.
Southern blot analysis showed that selection for DHFR gene amplification by increasing MTX resistance provided for the coamplification of IL-2 sequences. Hybridization studies of HeLa-pSDI-R200 DNA with IL-2 cDNA and DHFR cDNA probes detected several fragments in addition to bands of the same size as pSDI DNA (Figs. 3B and 3C). This result implies the existence of at least two independent integration points for the plasmid pSDI into this cell line's genome, or rearrangement of integrated pSDI DNA during amplification. Such rearrangement of transforming DNA has been observed in amplification processes. $^{32)}$

Amplified sequences containing plasmid pSDI DNA can be rescued by bacterial transformation. The amplification of DNA sequences by MTX increased the level of plasmid DNA in favor of rescue. Some rescued plasmids were thought to contain DNA sequences not derived from the original plasmid pSDI, and were probably complementary to locally repeated HeLa chromosomal DNA sequences, which were also amplified along with the pSDI DNA. Previous experiments have shown that rescued plasmid DNA from transformed cells contained host DNA. ${ }^{32)}$

The G-C stretch which was present between the SV40 promoter and the IL- 2 cDNA hampered gene expression. Its removal gave a $4 \sim 5$ fold increase in IL-2 secretion. Since the G-C bond is stronger than the A-T bond, it is likely that the G-C stretch hampers the movement of RNA polymerase during transcription.

It is now possible to obtain a large amount of IL-2 from both E. coli and human cells. Comparative studies on the pharmacokinetics and immunogenicity will find which preparation is preferable for medical use.

Acknowledgments. We thank Dr. Hiroshi Matsui for providing us with pCEIL-2, and Dr. Tsuyoshi Kobayashi, Mr. Masahiro Murata, and Mr. Tetsuya Miwa for valuable discussions.

\section{REFERENCES}

1) D. A. Morgan, F. W. Ruscetti and R. Gallo, Science, 
193, 1003 (1976).

2) S. Gillis, M. M. Ferm, W. Ou and K. J. Smith, Immunology, 120, 2023 (1978).

3) S. Gillis and K. A. Smith, Nature, 268, 154 (1977).

4) T. Taniguchi, H. Matsui, T. Fujita, C. Takaoka, N. Kashima, R. Yoshimoto and J. Hamuro, Nature, 302, 305 (1983).

5) R. Devos, G. Plaetinck, H. Cheroutre, G. Simons, W. Degrave, J. Tavernier, E. Remaut and W. Fiers, Nucleic Acids Res., 11, 4307 (1983).

6) T. Fujita, C. Takaoka, H. Matsui and T. Taniguchi, Proc. Natl. Acad. Sci. U.S.A., 80, 7437 (1983).

7) W. Grave, J. Tavernier, F. Duerinck, G. Plaetinck, R. Devos and W. Fiers, EMSO J., 2, 2349 (1983).

8) N. J. Holbrook, K. A. Smith, A. J. Fornace, Jr., C. M. Comeau, R. L. Wiscocil and G. R. Crabtree, Proc. Natl. Acad. Sci. U.S.A., 81, 1634 (1984).

9) S. A. Rosenberg, E. A. Grimm, M. McGrogan, M. Doyle, E. Kawasaki, K. Koghs and D. F. Mark, Science, 223, 1412 (1984).

10) G. E. Smith, G. Ju, B. L. Ericson, J. Moschera, H.W. Lahm, R. Chizzonite and M. D. Summers, Proc. Natl. Acad. Sci. U.S.A., 82, 8404 (1985).

11) J. Haynes and C. Weissmann, Nucleic Acids Res., 11, 687 (1983).

12) F. McCormick, M. Trahey, M. Innis, B. Dieckmann and G. Ringold, Mol. Cell. Biol., 4, 166 (1984).

13) R. Fukunaga, Y. Sokawa and S. Nagata, Proc. Natl. Acad. Sci. U.S.A., 81, 5086 (1984).

14) M. Yamada, J. A. Lewis and T. Grodzicker, Proc. Natl. Acad. Sci. U.S.A., 82, 3567 (1985).

15) Y. Gluzman, Cell, 23, 175 (1981).

16) C. C. Simonsen, UCLA Symp., 25, 1 (1982).

17) S. Subramani, R. Mulligan and P. Berg, Mol. Cell. Biol., 1, 854 (1981).

18) S. Gillis, M. M. Ferm, W. Ou and K. A. Smith, J. Immunology, 120, 2027 (1978).

19) H. Luthman and G. Magnusson, Nucleic Acids Res., 11, 1295 (1983).

20) W. Eckhart, Virology, 38, 120 (1969).

21) P. Southern and P. Berg, J. Mol. Appl. Genet., 1, 327
(1982).

22) M. Wigler, R. Sweet, G. K. Sim, B. Wold, A. Pellicer, E. Lacy, T. Maniatis, S. Silverstein and R. Axel, Cell, 16, 777 (1979)

23) G. Ringold, B. Dieckmann and F. J. Lee, Mol. Appl. Genet., 1, 165 (1981).

24) T. Maniatis, E. F. Fritsch and J. Sambrook, "Molecular Cloning. A Laboratory Manual," Cold Spring Harbor Laboratory, Cold Spring Harbor, New York (1982).

25) E. M. Southern, J. Mol. Biol., 98, 503 (1975).

26) R. T. Schimke, R. J. Kaufman, F. W. Alt and R. F. Kellems, Science, 202, 1051 (1978).

27) J. A. Hansen, P. J. Martin and R. C. Nowinski, Immunogenetics, 10, 247 (1980).

28) R. J. Robb, R. M. Kutny, M. Panico, H. Morris, W. F. DeGrado and V. Chowdhry, B. B. Res. Commun., 116, 1049 (1983).

29) G. Urlaub and L. A. Chasin, Proc. Natl. Acad. Sci. U.S.A., 77, 4216 (1980).

30) S. J. Scahill, R. Devos, J. V. Heyden and W. Fiers, Proc. Natl. Acad. Sci. U.S.A., 80, 4654 (1983).

31) R. J. Kaufman, L. C. Wasley, A. J. Spiliotes, S. D. Gossels, S. A. Latt, G. R. Larsen and R. M. Kay, Mol. Cell. Biol., 5, 1750 (1985).

32) R. J. Kaufman and P. Sharp, J. Mol. Biol., 159, 601 (1982).

33) C. S. Henney, K. Kuribayashi, D. E. Kern and S. Gillis, Nature, 291, 335 (1981).

34) S. Gillis, P. E. Baker, N. A. Union and K. A. Smith, J. Exp. Med., 149, 1960 (1979).

35) H. Wagner, C. Hardt, K. Heeg, M. Rollinghoff and K. Rfizenmaier, Nature, 284, 278 (1980).

36) F. Vanky, T. Gorsky, Y. Gorsky, M. G. Masucci and E. Klein, J. Exp.Med., 155, 83 (1982).

37) T. J. Eberlein, M. Rosenstein and S. A. Rosenberg, $J$. Exp. Med. 156, 385 (1982).

38) K. Welte, C. Y. Wang, R. Mertelsmann, S. Venuta, S. P. Feldman and M. A. S. Moore, J. Exp. Med., 156, 454 (1982). 